\title{
A Contemporary Interpretation of Tradition in Mosque Design. Marmara Ilahiyat Mosque, Turkey
}

\author{
Alev Erarslan, Assoc.Prof.Dr, \\ Department of Architecture, İstanbul Aydın University, Turkey
}

URL:http://dx.doi.org/10.19044/esj.2019.v15n8p97

\begin{abstract}
In recent years, the concept of contemporary mosque architecture has emerged in all Islamic countries. The goal of these structures which are produced using original designs, contemporary materials, technology and construction systems is to design structures which suit modern architectural concepts of today in the architecture of traditional mosques. Taken up with contemporary plan and form concepts rather than traditional plans, contemporary lines and interpretations are seen in liturgical elements such as the mihrap, dais, pulpit, gallerys, courtyard, fountain and minaret, which are indispensable elements of the mosque architecture in these mosques. One of the important points that is dwelled upon with these structures is their interior design.

The aim of this study is to examine the design, layout features as well as the interior decoration of the Marmara Ilahiyat Mosque, which is one of our contemporary mosques that have been addressed in Turkey in the $20^{\text {th }}$ century. With this goal, the structure's overall layout, its interior space, decorative and liturgic elements as well as characteristics such as materials, technology and lighting have been examined in detail. As one of the important representatives of contemporary Turkish mosques, the structure is suitable for the land it was built on top of and the city fabric, that it interprets traditional architecture with modern styling, and that it takes its place in a significant position amongst contemporary Turkish mosques, as it is a unique example that achieves a contemporary and dynamic identity of Turkish-Islamic architectures by using today's materials and techniques from a standpoint of traditional layout, plan elements and interior space embellishments.
\end{abstract}

Keywords: Marmara İlahiyat Mosque, contemporary mosques, interior decoration. 


\section{Introduction:}

As the primary structure of Islamic architecture, the mosque embarked on a quest towards symbolism and spatial awareness starting from the al Masjid al Mabawi in Medina (Grabar, 1993). Having different regional characteristics throughout the Islamic world, mosque architecture embarked on a search for new features in the $20^{\text {th }}$ century, undertaking various attempts as it preserved traditional plan elements. Traditional elements such as such as the mihrap, pulpit, minaret, courtyard, entrance riwak and women's gallery were interpreted in different forms with contemporary materials.

The broad, shallow layout seen in the early period of Turkish mosques which expanded transversely with adjacent support elements gradually transformed into a domed central space during the Ottoman era. The evolution in the historical process of the mosque structure continued in the Republican period as well, whereas the search for contemporary style gained momentum. Together with a changing perspective, mosque architecture became one of the important subjects of contemporary architecture.

The innovative attitudes in the plan, form, shape, covering and materials gained importance in contemporary Turkish mosques. As the classic cover in structures that were more biçimci, the dome is taken up from a more formalist perspective. Classic layouts have been abandoned entirely, whereas pure geometric and angle forms have been the preference in planimetry. As for the interior spaces, acoustics and ventilation issues have been taken up in line with the requirements of the day. Besides its functional requirement, lighting was also utilized with a symbolic purpose. The goal was to give these structures in which contemporary technologies were used a modern, dynamic look. However, it is seen that traditional Turkish-Islamic decorative arts were used in the embellishment characteristics in these structures which have completely modern indoor spaces.

The aim of this study is to examine the design and layout features, as well as the interior decoration of the Marmara Ilahiyat Mosque, which is one of Turkey's contemporary mosques of the $20^{\text {th }}$ century.

In examining the Marmara Ilahiyat Mosque, which is a significant example of contemporary mosques in Turkey, a general introduction of the structure is provided in this article, followed by the structure's layout and indoor characteristics. Moreover, the mosque's liturgic elements as well as features such as its interior decoration, materials and lighting have been taken up in this study.

\section{The Marmara Ilahiyat Mosque:}

Known by its full name, 'The Marmara University Theology Faculty Mosque and Cultural Center' the structure was constructed by the Mosque Commission and Revival Association of Marmara University's Faculty of 
Theology and designed by the founder of the Hassa Architecture Bureau, Master Architect Muharrem Hilmi Şenalp, who was also responsible for designing important buildings such as the Tokyo Mosque and Turkish Cultural Center, the Berlin Martyrs' Mosque and Cultural Center, the American Religious Center as well as the Istanbul Museum of the History of Science and Technology in Islam. Constructed in 2015, the structure is situated on land covering around $30,000 \mathrm{~m}^{2}$, including the front square and the cultural center beneath (Figure 1). As part of the Marmara University Theology Faculty complex, the building has $8,500 \mathrm{~m}^{2}$ of indoor space. In addition to serving as a house of prayer, it is also a culture center which provides opportunities for social and cultural activities such as an art gallery, classrooms, faculty member rooms, a library, an auditorium, exhibit halls, a bookshop café, cinevision rooms as well as a carpark (Uzun, 2010). The complex also offers charity sales, and special social, educational and cultural activities geared towards women and children. Established on triangular-shaped premises, the complex features auditoriums on three sides. The ablutions station on the west side has room enough to handle 134 ablutions simultaneously.

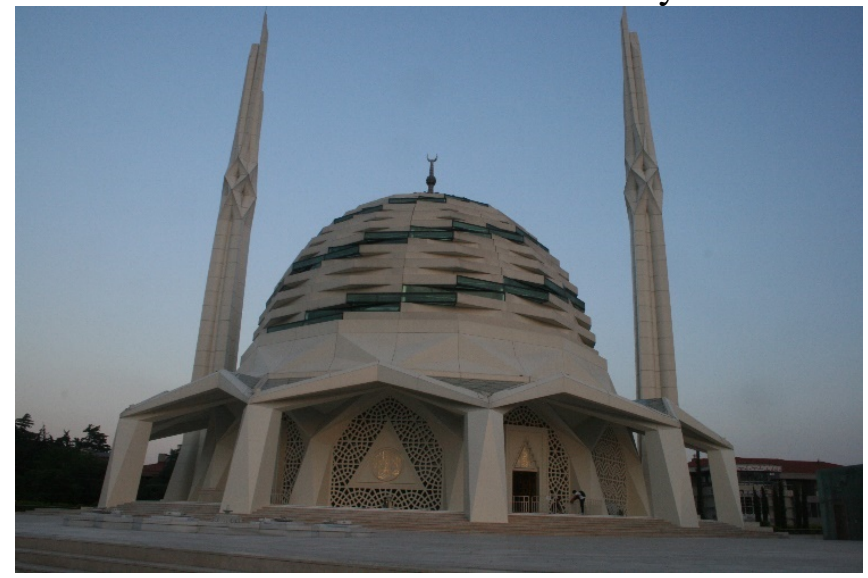

Figure 1: Marmara Ilahiyat Mosque (Alev Erarslan)

The four-storey structure that sits below the square and avenue elevation was constructed in a steel construction system over a reinforced concrete infrastructure. Glass, steel and fiber-reinforced concrete materials went into its construction. The ceiling of the structure's spacious foyer is criss-crossed with special steel beams designed in the manner of geometric girih patterns based on traditional architecture. The steel that forms the base plate for the geometric designs in the ceiling cladding and the modules that provide the illumination and star ceiling form are covered in fiberglass reinforced gypsum panelling (Akbulut, 2017). The cascading pool located in the foyer takes shape in the flooring with an opening of the geometric design, continuing in the floor ceramics as it goes from three dimension to two dimension, combining the 
space with the sound of water (Moustafa, 2014). The mosque is situated above the foyer floor.

Access into the mosque, which is the primary prayer venue of the complex, is through the wide front courtyard via the Mahir İz Avenue façade, and which is also utilized for funeral prayer ceremonies. There are means of circulation in the courtyard which provide access to the lower floors. Together with the courtyard, the complex has the capacity to handle 10,000 people, whereas the mosque, which has room for 5,000 people, has two floors, one on the upper part of the square, while the other is the underground basement floor. Each floor has its own main entrance. However, an inter-floor relationship can be established with the staircases and elevators inside the structure (Antel, 2013).

The dodecagon-planned two-storey mosque features a central plan layout covered with a dome on both floors. Situated in the structure's basement floor, the first floor has a dodecagonal shape comprised of 12 reinforced concrete pillars with a polygonal bisque (Figure 2). These 12 reinforced concrete polygonal pillars are linked to each other by segmented arches that sit on Turkish triangular decorative cantilevers. The corner bead spaces of the segmented arches are also ornamented with Turkish triangles. A dome measuring 27-m. wide and 19-m. high and comprised of Turkish triangles consisting of three tiers towers over this middle dodecagonal space which forms the center of the lower floor (Figure 3). A 16-pointed star motif is in the hub of the dome, whereas a band of Turkish triangles winds around the Turkish triangles. The word “Hu/hüve”, which means 'Him,' was written in celi sülüs calligraphy style by the mosque calligrapher Hüseyin Kutlu, in 16 pairs in the center of the dome.

An ambulatory corridor arranged with 12 pilaster-style pentagonalbodied columns embedded in the walls meander around the domed central dodecagonal middle space (Figure 4). Thus, the lower floor, which is comprised of two intertwining dodecagons, reminds us of the Kubbet-üs Sahra and the Kubbet-üs Süleybiye, which is regarded as the first tomb of

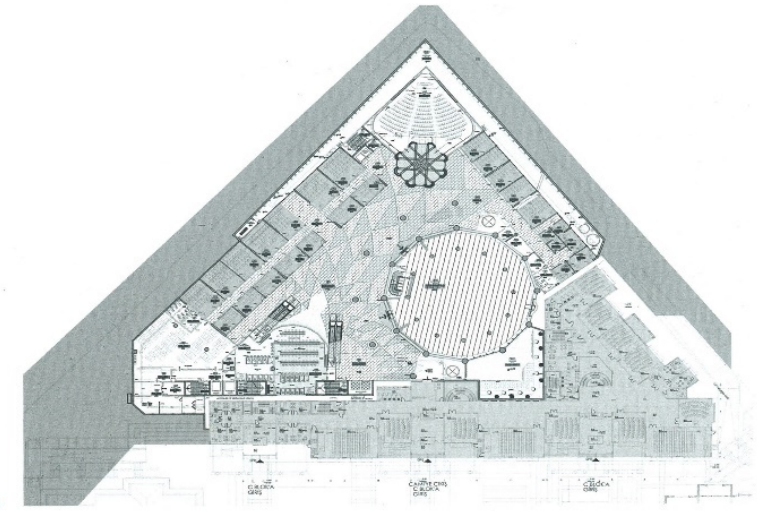

Figure 2: Lower floor layout (Hassa Architecture) 


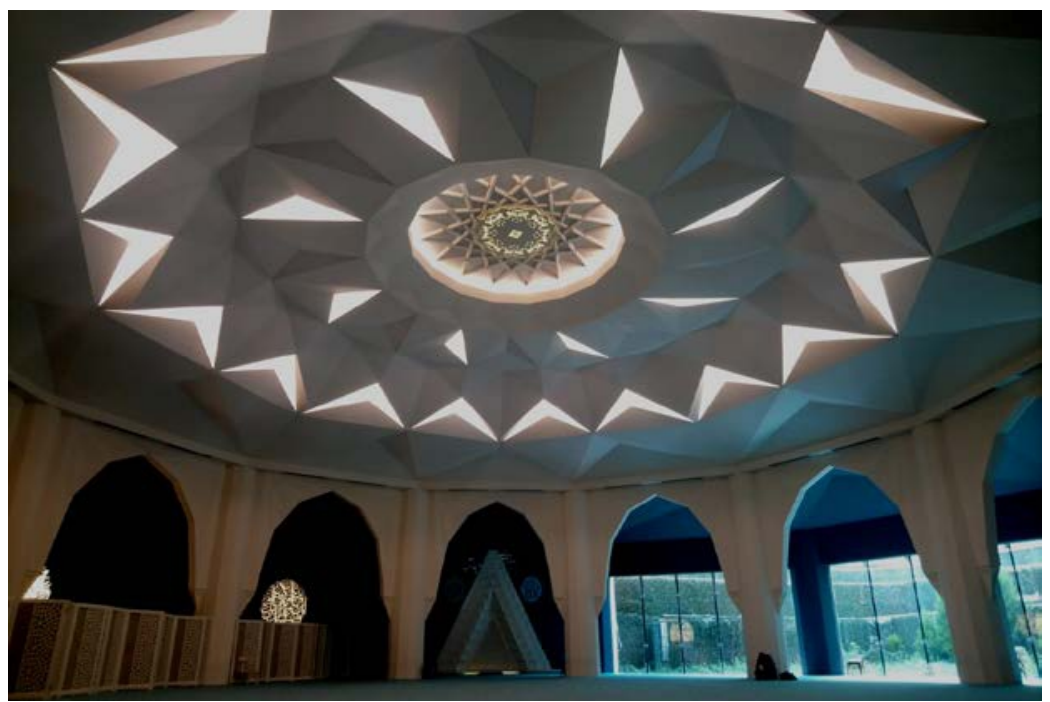

Figure 3: The lower floor praying space. Next to it, is the inner garden which provides the mihrap natural light (Alev Erarslan)

Islamic architecture. Once again, the main space features a covering system comprised of Turkish triangles above the ambulatory corridor which encircles the main space (Figure 4). Celi sülüs style Koranic verses inscribed in medallion are found on each surface of the dodecagonal walls of the ambulatory corridor, painted black and illuminated with a barrisol ceiling (Figure 4, 5).
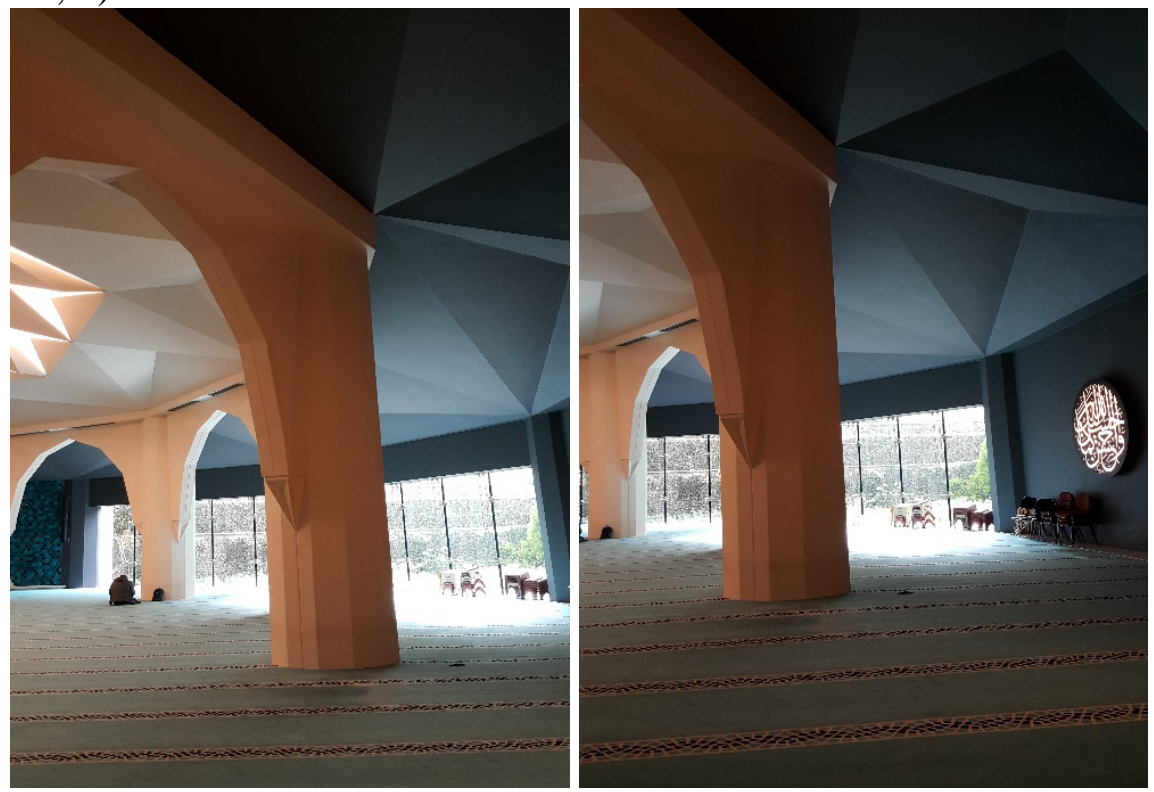

Figure 4: The ambulatory corridor encircling the main domed venue on the lower floor and one of the medallion in the walls of the ambulatory corridor with its Turkish triangular cover (Alev Erarslan) 


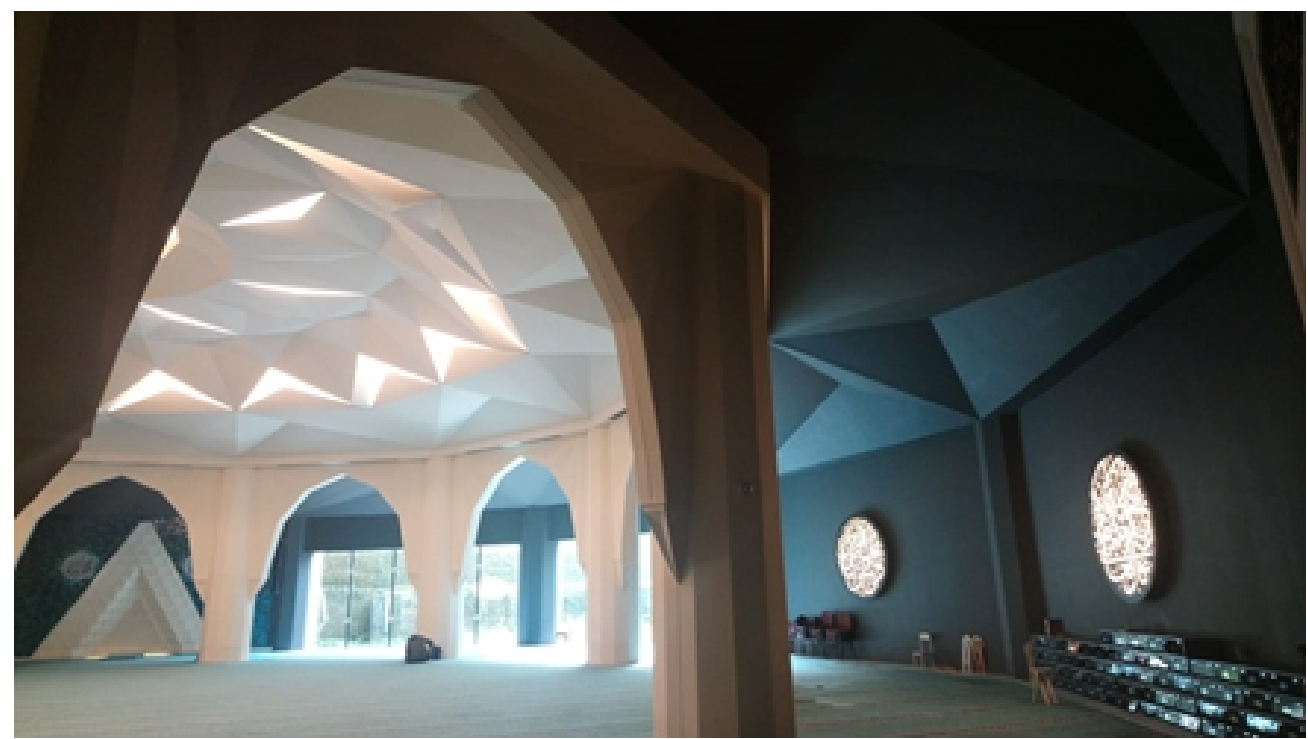

Figure 5: The ambulatory corridor encircling the main domed venue on the lower floor and the medallions in the walls of the ambulatory corridor (Alev Erarslan).

The mihrap of this floor was imbedded into the center of the qibla wall, behind the structure's ambulatory corridor. The mihrap was positioned between the structure's central domed dodecagonal main prayer space and one of the segmented arches that link the polygonal pillars supporting the dome (Figure 6). Garnering attention for its unique design, the mihrap edges feature a segmented triangular shape. Fashioned from fiber-reinforced concrete, there are inside-out Turkish triangles, hexagonal stars and borders comprised of hipped, pointed arches around its surface. Embellishment comprised of hexagonal stars inside the niche arch is found in the center of the mihrap, whereas the surface around the niche is covered with turquoise tiles. The $115^{\text {th }}$ verse of the Bakara Sura, which reads "fe eynema tuvellu fe semme vecullah", which means "Allah is everywhere you look" inscribed in 'celi sülüs' within the medallions on either side of the mihrap (Figure 6, 7). The mihrap has been illuminated by ensuring natural lighting with a garden situated in line with the qibla wall. For this reason, the wall on this side is comprised of a glass surface in order to illuminate the mihrap with natural light (Figure 5). 


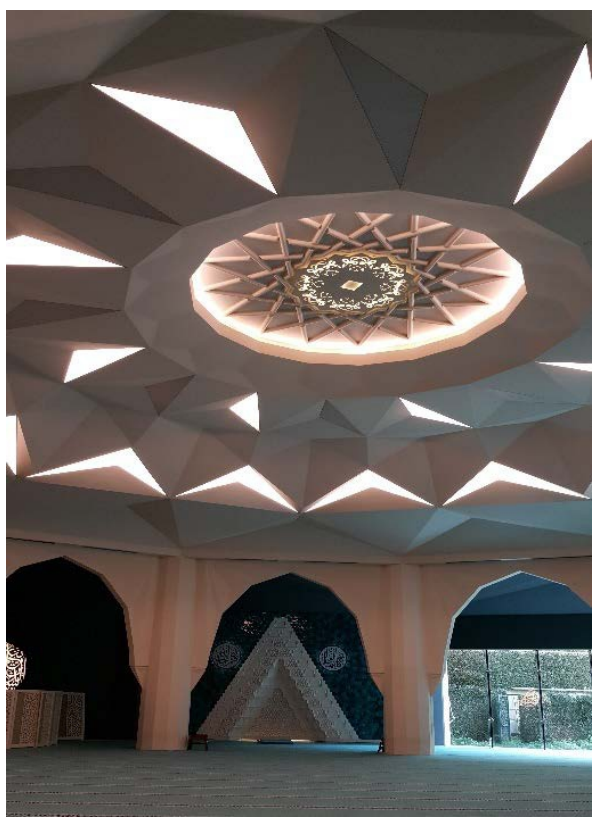

Figure 6: The mihrap which is positioned behind the ambulatory corridor on the lower floor (Alev Erarslan)

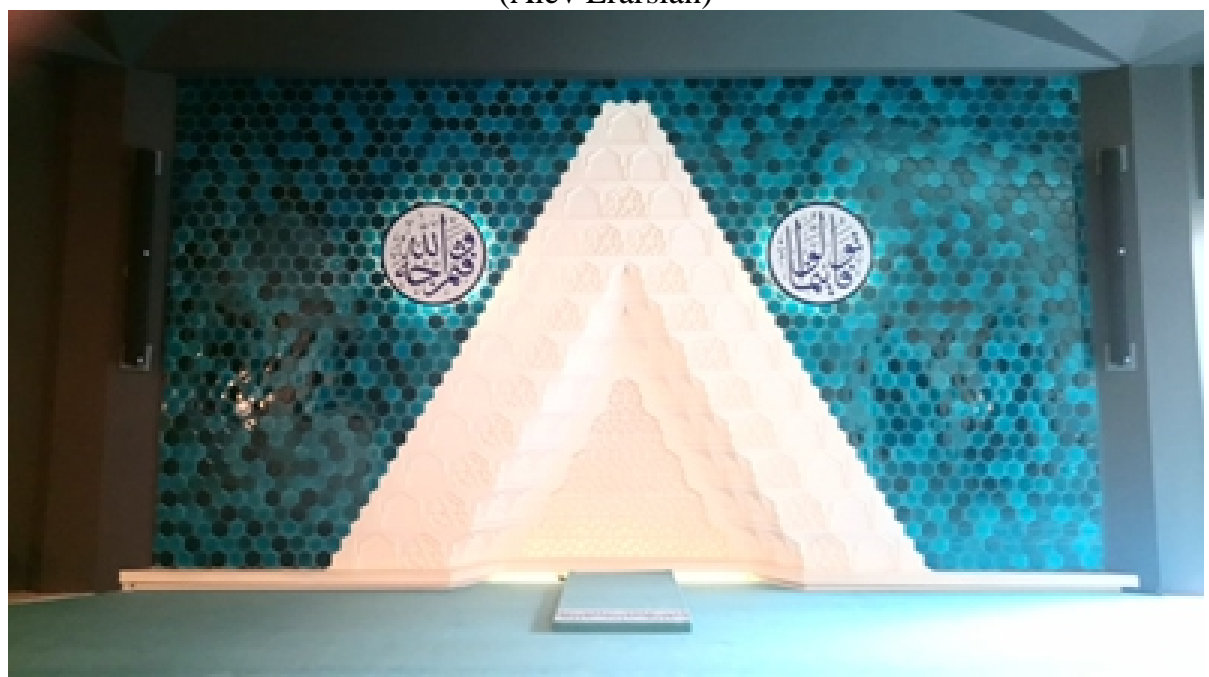

Figure 7: The mihrap in the lower floor and the medallions (Alev Erarslan)

The women's gallery of this floor is in the building's eastern end, inside the ambulatory corridor in this direction and separated by a wooden partition painted in white and covered with geometric systems composed of polygonal stars interwoven with Shahi spots 'çintemani' and double-striped Pelengi motifs (Figure 3). One enters this floor via a pair of double-winged doors crafted in the geometric 'kündekari' technique on other side of the elevator. There is celi sülüs style calligraphy inside the cartridges over the door trunks which were designed in the style of Seljuq victory gates. 
Accessed from the Mahir Iz Avenue façade, the upper floor of the building features a triple section riwak in front, which is once again comprised of Turkish triangles, sitting atop four columns (Figure 1). Having assumed the task of entrance, there are two entrances beneath this riwak, situated to the right and left of the structure, which are crafted from the modern kündekari technique, with trunks designed to look like Seljuq victory gates. The main prayerping space on the upper floor features a dodecagonal layout set up with 12 concrete pillars with Turkish triangular trunks. These pillars are linked to each other with pointed arches. The glass of the arches is coated with sunscreens decorated with geometric girih artwork comprised of polygonal star compositions. Consequentially, pointed arches, the insides of which feature geometric decorations, make up the dodecagon of this floor's façade (Figure 8). The design of this façade ensures a distinctive illumination of the interior spaces with light and shadows. The insides of the arch corner pieces feature medallions that were inscribed with the 'Names of Allah' (Esma-ül Hüsna) in 'celi sülüs' style by mosque calligrapher Hüseyin Kutlu (Figure 8, 10 ). This dodecagonal layout prayer venue is covered by a dome measuring 32-m. wide and 35-m. high which is supported by 12 pillars (Evren, 2009).

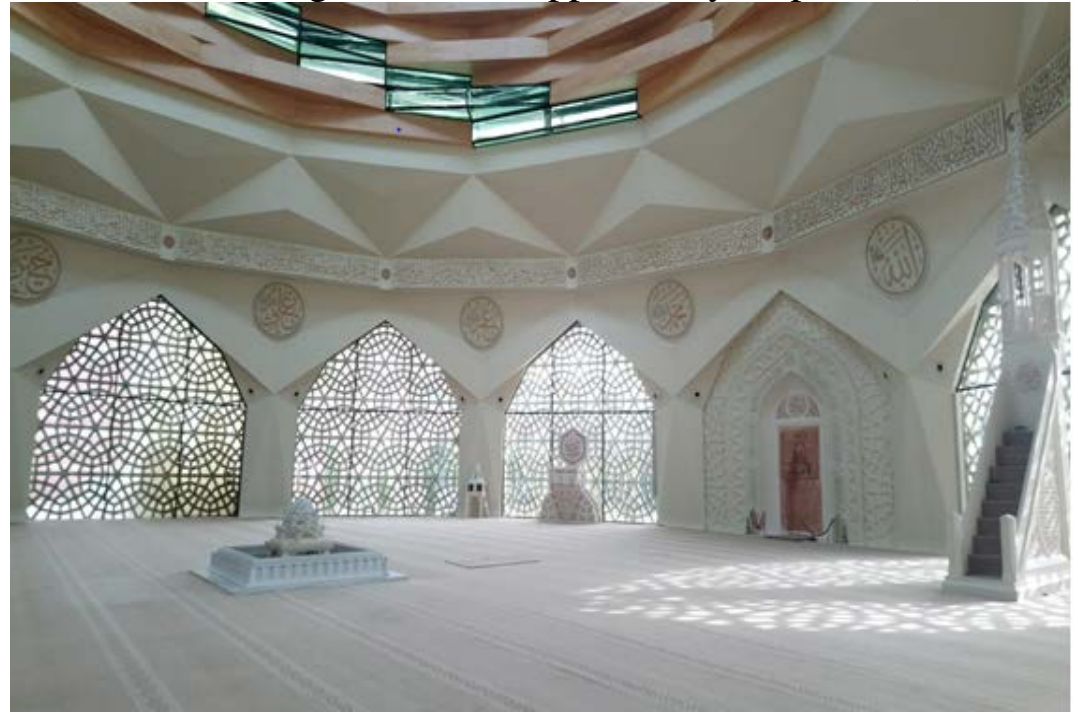

Figure 8: The prayer venue on the upper floor. Mihrap and the geometric decorated shading insides linking the pillars (Alev Erarslan)

Fiberglass reinforced concrete-coated dome over steel construction went into the shape of the "swallow dome" which is unique to Central Asia and Anatolia, with the most famous example seen in the Erzurum Ulu Mosque. Its interior was given the look of a staggered helezonic spiral appearance using wood and glass (Figure 7) (Akın, 1991). A 'wheel-of-fortune' (çarkı felek) motif has been formulated which relates God's perfection with glass surfaces between the wooden material (Figure 9). Concurrently, these glass spacers 
also ensure the structure receives natural light. The octagonal luminous glass skylight in the center of the dome is unique to Turkish architecture, its surface is also composed of Turkish triangles. The six intertwining vav inscriptions are striking in the heart of the dome (Figure 9). The transition element to the dome is a Turkish triangle belt found on the dome hoop. Each of the dodecagonal surfaces of the dome hoop are inscribed with examples of 'celi sülüs' style calligraphy. The light-shadow façade and the glass used in the covering constitute the strongest source of natural light on this floor. The steel dome pinnacle is topped by a special star and crescent which lights up at night.

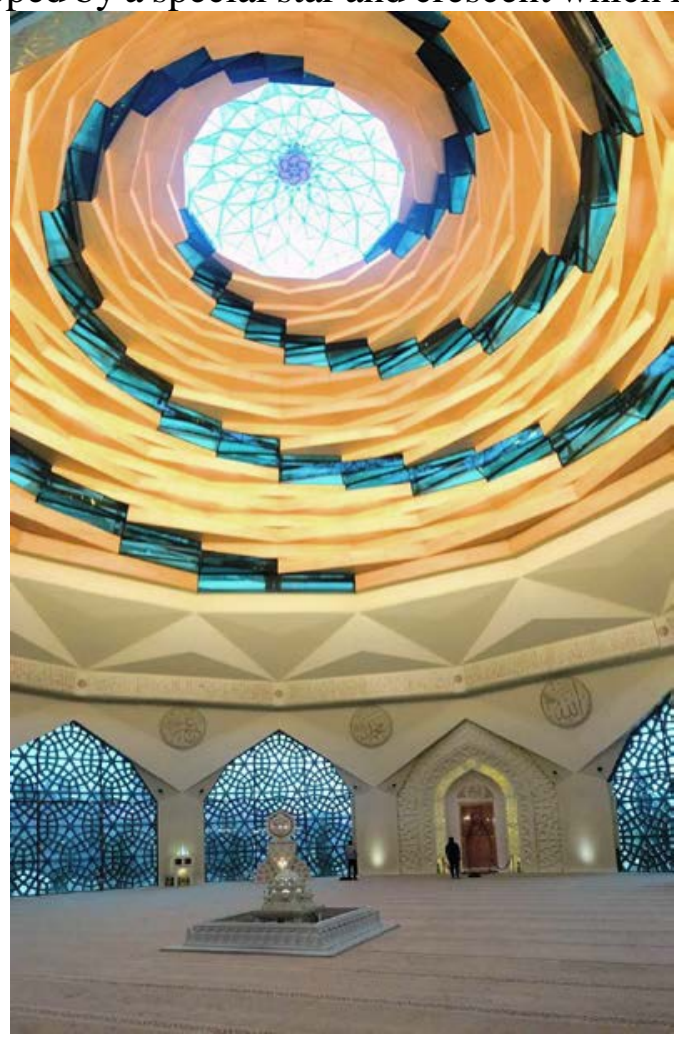

Figure 9: The swallow dome with ‘Wheel of Fortune’ (çarkıfelek) glass luminuous intervals covering the upper floor praying space and mihrap and fountain (Emre Duyan).

The mihrap niche of this floor was placed on the surface of one of the pointy dodecagonal arches which comprise the niche wall. The main arch of the pointed arch niche and the muqarnas kavsara were hewn from red marble and the borders were made of fiber-reinforced concrete (Figure 8). The three borders around the niche are comprised of sun motifs, two of which feature Turkish triangles while the inside of the third was inscribed with the Ayet-el Kursi in the celi muhakkak calligraphy style (Figure 10). The space beyond the arch is comprised of transitive polygonal stars. 


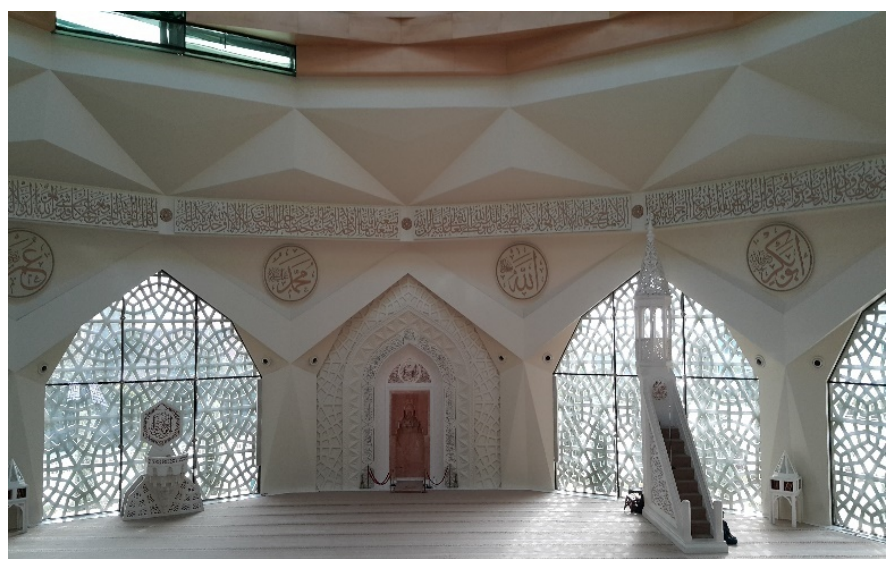

Figure 10: The mihrap, pulpit (minber) and sermon dais (vaaz kursu) of the upper floor prayer venue (Alev Erarslan)

Once again, the pulpit of the mosque's upper floor praying area was made from fiber-reinforced concrete, whereas it features a large star composition in the center of the side mirror with a colorful rumi-palmette band around it (Figure 11). The pulpit has a bannister and geometric girih art comprised once more from stars is seen in the pulpit pavilion. The surface of the cone of the pulpit pavillion is decorated with rumi-palmette motifs. The muezzin gallery situated to the east of the pulpit was made from fiberaddititive concrete materials and features a hexagon backboard, and eightpoint star balustrade and is in the manner of the gallery's sub-muqarnas console. Again, the gallery pedestals are comprised of multi-branched stars.

As for the minbar on this floor, it was cast from fiber-reinforced concrete, whereas the balcony sits atop a maqarnas console. The walls of the minbar are decorated with geometric girih. The minbar's seat headrest is hexagonal,
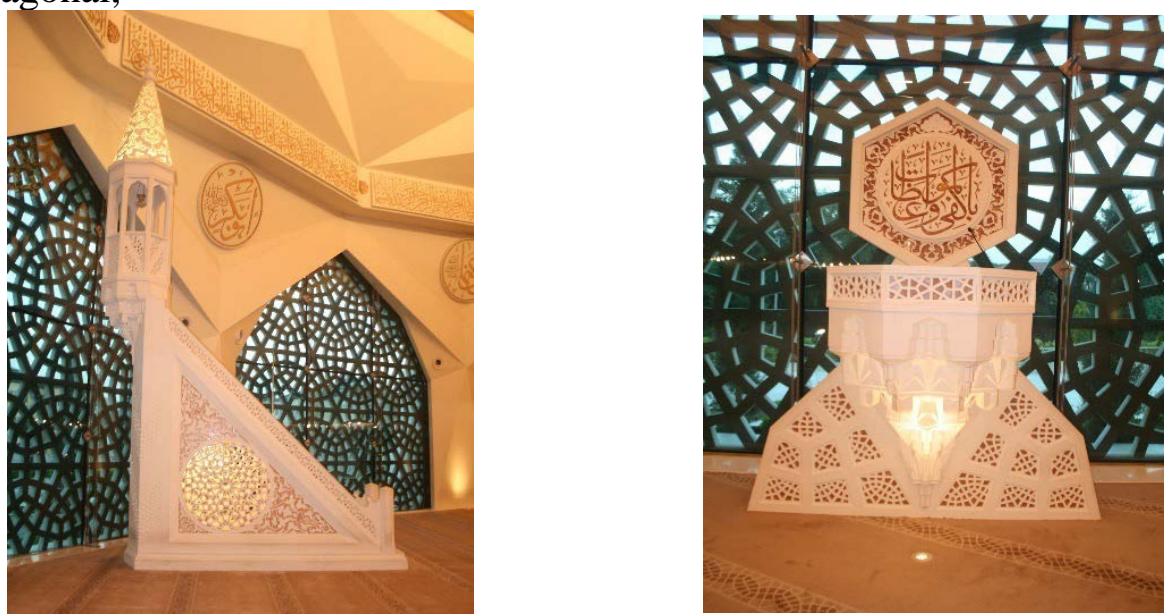

Figure 11: The pulpit (minber) of the upper floor prayer venue and the kürsü (Alev Erarslan). 
whereas its inside was inscribed in 'celi sülüs' with the Arabic phrase "Elmeytu vaizen kefa," meaning "death as a sermon is sufficient". In the exact center of this floor, beneath the dome's glass luminous opening, is a mosqueshaped fountain within the pool of the fountain (Figure 9, 11). Adding a refreshing effect to the structure's interior, this water effect is reminiscent of the fountain and fountain pools beneath the muezzin galleries found in the Bursa Ulu, Kütahya Ulu and Edirne Selimiye Mosques. However, the mosqueshaped fountain element recalls to a greater extent the fountain in the Bursa Yeşil Mosque.

The women's gallery on this floor is towards the structure's entrance found in the north and is comprised of a mezzanine floor situated over the structure's two entrance gates (Figure 12). A partition with geometric ornamentation crafted over glass using the sandblasting techniqe stretches in front of the single-floor women's gallery. Inscriptions of Hatice r.a and Fatıma r.a.are written in the medallions in the walls of the women's gallery.

The structure has two doors that open into the main praying venue and were produced with glass surfaces, using the modern straight 'kundekari' technique. building's elevator was positioned between the pair of entrance doors on both floors and was produced on glass using a geometric decorative sandblasting technique.

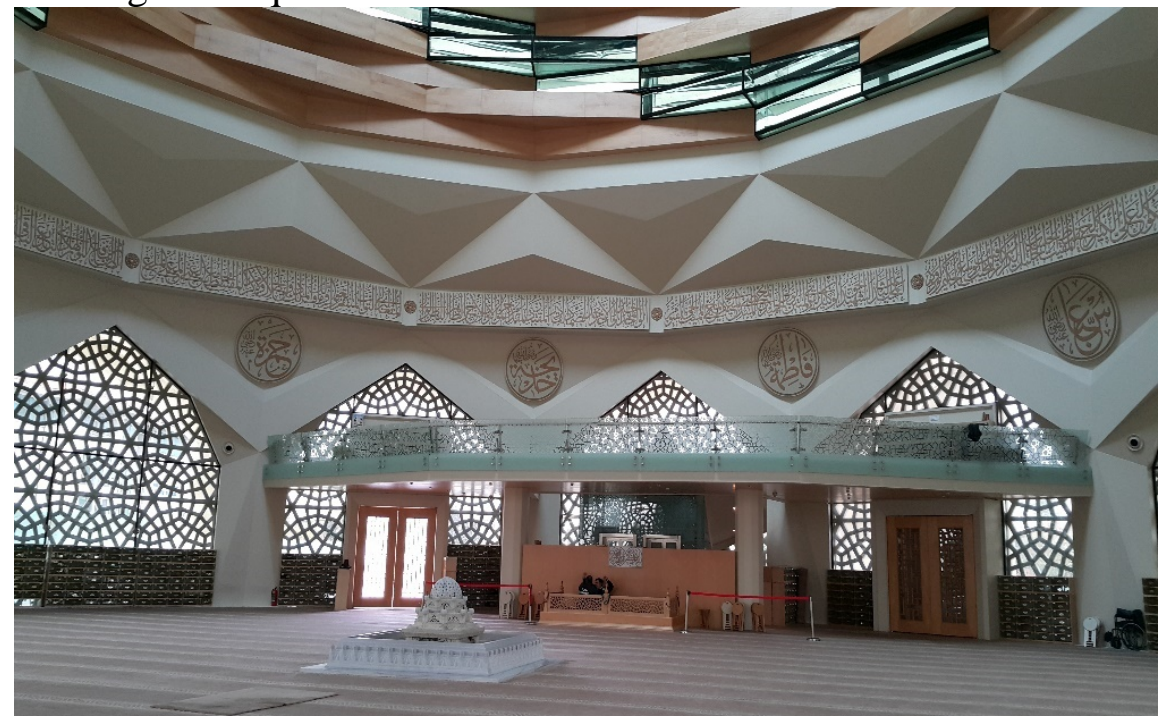

Figure 12: The women's gallery towards the top floor entrance and the fountain beneath the dome (Alev Erarslan)

The structure's interior on both floors was designed plainly and simply in order to ensure peace of mind during prayers so the congregations concentrate on worshipping. The light colors used in the interior also give a spacious feel to the building. In addition to the mosque's floor heating system which is facilitated electrically via carbon filaments inside PVC cables laid 
under the carpet, heating is also ensured by means of a mechanical climatization system with pipes imbedded into the structure's shell, along the upper edges of the glass surfaces (Atmaca, Gedik, 2017). Fresh air is sent into inside through vents situated on the floor in front of the glass pointed arches on the upper floor. The underfloor heating system switches to sleep mode once the desired indoor temperature is reached via sensors in the structure, which operates advanced air conditioning systems (Atmaca, Gedik, 2017).

Contrary to classic layouts, the courtyard of the mosque is on the upper floor and is not surrounded by walls. Standing at a height of $57.8 \mathrm{~m}$., the structure's two minarets were positioned in the direction of the structure's qibla wall. The minarets have a wide infrastructure and are polygonal in shape, far from the design of classic minarets. Instead of the normal minaret galleries, there is a section comprised of Turkish triangles in the shape of diamond segments. Tapering off towards the top, the minarets point out from this section upwards (Figure 1). The steel construction minarets are clad with fiberreinforced multiform material.

\section{Conclusion:}

As an important representative of contemporary Turkish mosques, the Marmara Ilahiyat Mosque is a structure that interprets traditional architecture in a modern style. Suitable for the urban makeup and the land where it is was built, the structure reflects the Ottoman-Islamic architectural style in terms of its layout and interior decoration.

As a successful example of the central space concept covered by a dome, which is the most fundamental ideal of Classic-era Ottoman architecture, the dome was used as a plan archetype that determines the shape rather than a functional cover. In giving the space a sense of character to the space, the dome was designed differently on both floors and has become integrated with the space. An intense Turkish triangle effect is felt in the design and interior decoration of the structure. There is an extremely open and spacious space effect on both floors.

Traditional layout elements and Turkish-Islamic decorative arts were implemented to give the structure a contemporary and dynamic identity by using modern day materials and techniques. The traditional ornamental motifs used in the structure are not only embellishing elements but are also used as elements that reinforce their influence. With its stylistic features and composition, the mosque holds an important position among contemporary Turkish mosques. 


\section{Acknowledgement}

I would like to offer thanks to Abdullah Said Taşdemir for translating Arabic calligraphy and thank my dear student Emre Duyan for taking a great shot photo (Fig 9).

\section{References:}

1. Akbulut, N. (2017). Türkiye'de Çağdaş Cami Mimarisi Tasarımında Yenilikçi Yaklaşımlar, İstanbul Aydın Üniversitesi, Unpublished Master Thesis, İstanbul.

2. Akın, G. (1991). Tüteklikli Örtü Geleneği: Anadolu Cami ve Tarikat Yapılarında Tüteklikli Örtü. Vakıflar Dergisi 22: 323-354.

3. Antel, A. (2013). Geçmişten Günümüze Camii Mimarisinde Gelişim, I. Ulusal Camii Mimarisi Sempozyumu. Geleneksel Geleceğe Camii Mimarisinde Çağdaş Tasarım ve Teknolojiler 2-5 Ekim 2012 Mimar Sinan Güzel Sanatlar Üniversitesi, 57-262.

4. Atmaca, A. B., Gedik, G. Z. (2017). Dini Yapıların Isıl Konforunun İncelenmesi: Marmara İlahiyat Cami ve Hz. Ali Cani Örneklemeleri, 13. Ulusal Tesisat Mühendisliği Kongresi, 19-22 Nisan 2017, İzmir, 1253-1262.

5. Evren, E. (2013). Modernlik ve Türkiye'de Modern Camiler, Antalya.

6. Frishman, M. (1994). İslam and the Form of the Mosque, Martin Frishman, Hasan-Uddin Khan (Ed), The Mosque: History, Architectural Development and Regional Diversity, London, 17-41.

7. Grabar, O. (1993). Symbols and Signs in Islamic Architecture, Renata Holod, Darl Rastorfer (Ed), Architecture in Continuity: Building in the Islamic World Today, New York, 25-32.

8. Güzer, A. C. (2009). Modernizmin Gelenekle Uzlaşma Çabası Olarak Cami Mimarlığ , Mimarlık 348: 21-23.

9. Moustafa, A. M. A. (2014). Contemporary Mosque Architecture in Turkey, The American University in Cairo, School of Humanities and Social Sciences, Cairo.

10. Uzun, Ç. (2010). Günümüz Cami Mimarisinin İşlev-Biçim ve Teknoloji İlişkisi Açısından İncelenmesi, Unpublished Master Thesis, İzmir. 